\title{
The Activity of Wungu Leaf (Graptophyllum pictum (L) Griff) Extract in Reducing Blood Glucose Level of Hyperglycemic Mice
}

\author{
Hayatul Rahmi ${ }^{1 *}$, I Made Artika ${ }^{1}$, Norman Razief Azwar ${ }^{1}$, Djarot Sasongko Hami Seno ${ }^{1}$, Waras \\ Nurcholis ${ }^{1}$
}

Department of Biochemistry, Bogor Agricultural University (IPB), Bogor 16680, Indonesia

*Corresponding author: Hayatul Rahmi; Department of Biochemistry, Agatis street, Animal Science building 5th floor, Bogor 16680; email: hayatulrahmi16@yahoo.com

\section{ABSTRACT}

Wungu leaf (Graptophyllum pictum (L.) Griff) is a plant thought to have potential use in alleviating symptoms of diabetes mellitus. The purpose of the present study was to evaluate the activity of wungu leaf extracts in decreasing blood glucose level of alloxan (200 $\mathrm{mg} / \mathrm{kg} \mathrm{BW}$ )-induced hyperglycemic mice. Extracts of wungu leaf were obtained by macerating with ethanol and then partitioning the extract with diethyl ether, ethyl acetate, and butanol. Each extract obtained was used to treat hyperglycemic mice for 28 days. The results showed that wungu leaf extracts have the ability to decrease the blood glucose level of hyperglycemic mice (dose $50 \mathrm{mg} / \mathrm{kg} \mathrm{BW}$ ). The ethyl acetate extract showed the highest activity, bringing about a decrease of blood glucose of $37.6 \%$. The wungu leaf extract has the potential to be developed as a source of anti-diabetic agents.

Keywords: Graptophyllum pictum (L.) Griff, partition extraction, ethyl acetate

\section{INTRODUCTION}

Diabetes mellitus is a chronic disease characterized by high blood-glucose levels (hyperglycemia) caused by a decrease of the hormone insulin. The insulin cannot be produced in normal level because of $\beta$ cells pancreatic damage, and also because of the lack of responsiveness of body cells to insulin. This decrease of insulin function, influences the metabolism of carbohydrates, lipids and proteins (Studiawan and Santosa 2005).
There are many ways which have been taken to control diabetes, ranging from dietary adjustments and regular exercise, to the use of synthetic anti-diabetic drugs or even by insulin injection. The value of synthetic anti-diabetic drugs have been reduced on the market because of the emergence of herbal medicines. This is because of the effects of herbal medicines are not harmful if taken according to the recommended dosage, in addition to their cheaper price compared to the synthetic medicines (Sunarsih et al. 2007). 
There are some plants which have been studied and have been indicated to have antidiabetic activity including gods crown, makasar fruit, brotowali, and nony. Some of these plants belong to the family Acanthaceae, making other plants of this family likely candidates to have anti-diabetic activity, one of which is the wungu leaf (Graptophyllum pictum (L.) Griff). The wungu leaf has been used by people in the healing of various diseases, such as hemorrhoids, ulcers, sore ears and stomachs, as well as facilitating the menstrual cycle for women (Dalimartha 1999).

Several other studies on wungu leaf are related to the effect of the active compounds found in the wungu leaf such as alkaline phosphatase activity (Widyowati 2011), isolation of the main metabolite compounds [Graptophyllum pictum (L.) Griff and BSLT (Brine Shrimp Lethality test) (Zuhra and Lenny 2005)], in vivo studies of wungu leaf extracts such as wungu leaf estrogenic effects on ovaryectomized mice (Suhargo 2005), as well as research on oxytocic and anti-implantation of the wungu leaf (Olagbende-Dada et al. 2009).

Research by Nurcholis et al. (2011) showed that a water-ethanol extract of the wungu leaf is effective as an inhibitor of $\alpha$-glucosidase enzyme. The work of OlangbedeDada et al. (2011) also reinforces the wungu leaf as an anti-diabetic agent from the results of studies showing the efficacy of hypoglycemic wungu leaf extracts. Existing studies have not revealed the mechanism of action of metabolite compounds wungu leaf which are effective as an anti-diabetic agent. Therefore this study was conducted to determine the activity of compounds from the medicinal plant wungu leaf in alleviating symtoms of diabetes mellitus.

\section{MATERIALS AND METHODS}

\section{Materials}

The leaves of G. pictum (L.) Griff were collected from the Conservation and Cultivation Unit of the Biopharmaca Research Center, Bogor Agricultural University. Ethanol 96\%, diethyl ether, ethyl acetate, butanol, glibenclamide, alloxan, tween 80 , were obtained from pharmacy shops in Bogor, Indonesia. The mice Sprague-dawley strain were obtained from Faculty of Veterinary Medicine, Bogor Agricultural University. All of the chemical and the solvents used were of analytical grade.

\section{Extraction Plants Wungu leaf}

Extraction was done by maceration with a comparative range of samples and solvents (ethanol $96 \%$ ) 1:10 for 1x24 hours, 1 minute during the first 6 hours plaud in a shaker according to the procedures developed by Nurcholis et al. (2011). Samples were filtered and the filtrate obtained was collected and evaporated with a rotary evaporator at a temperature of $40^{\circ} \mathrm{C}$. The ethanol extract was dissolved in water, shaken and extracted by partitioning with a separating funnel, first with diethyl ether $(2 \times 50$ $\mathrm{mL}$ ), followed by ethyl acetate and finally with butanol. Furthermore, each filtrate was evaporated on a rotary evaporator to yield diethylether, ethylacetate, and butanol extracts.

\section{Treatment to the experimental animals}

The experimental animals were male mice around 2-3 months-old weighing 140-210 grams. Diabetes was induced by alloxan intraperitoneal injection $(200 \mathrm{mg} / \mathrm{kg}$ weight). Treatment was divided into 7 groups $(\mathrm{A}, \mathrm{B}, \mathrm{C}, \mathrm{D}, \mathrm{E}, \mathrm{F}$, $\mathrm{G})$ with the number of mice per group as follow 
Table 1 Treatment of mice each group

\begin{tabular}{lll}
\hline No. & Group & Treatment \\
1 & $\mathrm{~A}$ & normal, non-alloxan treatment given $1 \mathrm{~mL} 5 \%$ tween 80 \\
2. & $\mathrm{B}$ & positive control, glibenclamide $0.25 \mathrm{mg} / \mathrm{kg} \mathrm{BW}$ in $1 \mathrm{~mL} 5 \% \mathrm{v} / \mathrm{v}$ tween 80 \\
3. & $\mathrm{C}$ & negative control given $1 \mathrm{~mL} 5 \% \mathrm{v} / \mathrm{v}$ tween 80 \\
4. & $\mathrm{D}$ & ethanol extract $50 \mathrm{mg} / \mathrm{kg} \mathrm{BW} \mathrm{in} 1 \mathrm{~mL} 5 \% \mathrm{v} / \mathrm{v}$ tween 80 \\
5. & E & diethyl ether extract $50 \mathrm{mg} / \mathrm{kg} \mathrm{BW}$ in $1 \mathrm{~mL} 5 \%$ v/v tween 80 \\
6. & F & ethyl acetate extract $50 \mathrm{mg} / \mathrm{kg} \mathrm{BW} \mathrm{in} 1 \mathrm{~mL} 5 \%$ tween 80 \\
7. & G & butanol extract $50 \mathrm{mg} / \mathrm{kg} \mathrm{BW}$ in $1 \mathrm{~mL} 5 \%$ tween 80 \\
\hline
\end{tabular}

Table 1. The treatment was done over 14 days. Blood glucose was measured with a glucometer on the first day before the treatment and at 1 hour after administration of the treatment on days 4 , 7, 10 and 14 (Rauter et al. 2009).

\section{Statistical Analysis}

The study design used was a completely randomized design using the SAS 9.1 program to analyze blood glucose levels, and followed by the Duncan's test, which consists of 7 treatments with each treatment consisting of 4 replicates.

\section{RESULTS}

Data showed that the wungu leaf extracts have the ability to decrease the blood glucose level of alloxan-induced hyperglycemic mice. The blood glucose levels of each mice group

Table 2 Data on average of blood glucose levels (mg/dL) of each group of mice

\begin{tabular}{cccccc}
\hline Group & day 1 & day 4 & day 7 & day 10 & day 14 \\
\hline A & $62.2 \pm 10.7 \mathrm{a}$ & $81.5 \pm 5.2 \mathrm{~b}$ & $98.7 \pm 14.5 \mathrm{a}$ & $84.7 \pm 12.7 \mathrm{c}$ & $79.0 \pm 14.3 \mathrm{~b}$ \\
$\mathrm{~B}$ & $59.0 \pm 7.8 \mathrm{a}$ & $173.2 \pm 324.0 \mathrm{a}$ & $138.5 \pm 60.7 \mathrm{a}$ & $85.0 \pm 11.2 \mathrm{c}$ & $75.2 \pm 8.2 \mathrm{~b}$ \\
$\mathrm{C}$ & $55.7 \pm 12.0 \mathrm{a}$ & $141.3 \pm 41.6 \mathrm{a}$ & $138.3 \pm 34.2 \mathrm{a}$ & $130.0 \pm 17.5 \mathrm{a}$ & $117.2 \pm 12.4 \mathrm{a}$ \\
$\mathrm{D}$ & $57.2 \pm 10.7 \mathrm{a}$ & $132.3 \pm 38.0 \mathrm{a}$ & $125.034 .5 \mathrm{a}$ & $112.0 \pm 17.8 \mathrm{ab}$ & $89.3 \pm 26.6 \mathrm{ab}$ \\
$\mathrm{E}$ & $58.7 \pm 16.0 \mathrm{a}$ & $131.0 \pm 36.3 \mathrm{a}$ & $120.3 \pm 29.2 \mathrm{a}$ & $98.0 \pm 4.9 \mathrm{bc}$ & $91.5 \pm 12.6 \mathrm{ab}$ \\
$\mathrm{F}$ & $55.0 \pm 5.8 \mathrm{a}$ & $130.0 \pm 2.16 \mathrm{a}$ & $117.0 \pm 9.2 \mathrm{a}$ & $82.0 \pm 14.5 \mathrm{c}$ & $81.0 \pm 8.8 \mathrm{~b}$ \\
$\mathrm{G}$ & $53.2 \pm 11.5 \mathrm{a}$ & $138.0 \pm 53.7 \mathrm{a}$ & $121.5 \pm 33.1 \mathrm{a}$ & $78.5 \pm 18.0 \mathrm{c}$ & $93.0 \pm 29.1 \mathrm{ab}$ \\
\hline
\end{tabular}

Description: The index numbers followed the same letter within a column indicate no significant difference between treatments $(\mathrm{p}>0.05)$

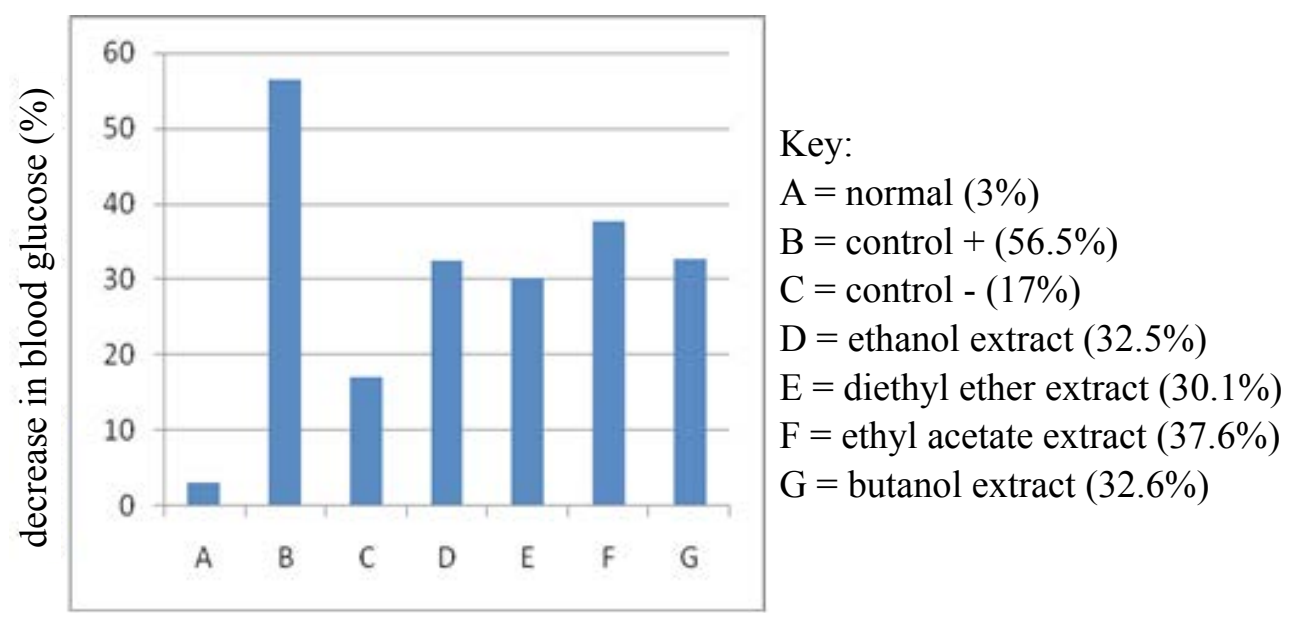

Figure 1 The percentage of glucose-decreased levels in blood of each treatment-group 
on day 1 , day 4 , day 7 , day 10 and day 14 are shown in Table 2 . The percentage of glucose level decrease of each group is shown in Figure 1. The reduction of blood glucose level due to treatment with wungu leaf extract ranged from $32.5 \%$ to $37.6 \%$. The most active extract was the ethyl acetate extract bringing about a decrease blood glucose level of $37.6 \%$.

\section{DISCUSSION}

From Table 2, blood glucose levels in mice in group A showed normal blood glucose levels. levels. This was due to untreated mice being force-fed with only $1 \mathrm{~mL}$ of $5 \%$ tween 80 . On the first day the blood glucose level was 62.2 \pm 10.7 with a $23.6 \%$ increase on day 4 and a $17.4 \%$ at day 7 . While on day 10 it decreased by $16.5 \%$, and it decreased on day 14 by $7.2 \%$. However the group A blood glucose value is still in the normal range.

In group B (positive control) mice 200 $\mathrm{mg} / \mathrm{kg} \mathrm{BW}$ were alloxan-induced and forced fed $0.25 \mathrm{mg} / \mathrm{kg} \mathrm{BW} /$ day glibenclamide in $5 \%$ tween 80. On day 1 of normal blood glucose levels the value was $59.0 \pm 7.8$ and on day 4 it rose $65.9 \%$ after alloxan treatment. This suggests that alloxan had an effect on the mice body marked by the rise of blood glucose which exceeded normal limits. Alloxan works by destroying pancreatic $\beta$-cells by inducing the formation of hydroxyl-free radicals which then attack the pancreatic $\beta$-cells essential component such as the plasma membrane, lysosomes, mitochondria and DNA and into the early destruction of pancreatic $\beta$-cells (Fahri et al. 2005)

Blood glucose levels drop back down on days 7,10 , and 14 respectively $20.0 \%$, $62.9 \%, 13.0 \%$. This is because the provision glibenclamide which can inhibit pancreatic $\beta$-cell damage caused by alloxan. Based on the results of the statistical analysis, the glibenclamide treatment significantly affected blood glucose mice at all times observed according to the fact that glibenclamide works principly as one of a group of sulfonylurea derivative drugs that have the potential of lowering blood glucose levels better than other types of sulfonylurea compounds (Fahri et al. 2005).

In group $\mathrm{C}$ (negative control) mice were induced with alloxan $200 \mathrm{mg} / \mathrm{kg} \mathrm{BW}$ and given $1 \mathrm{~mL}$ of $5 \%$ tween 80 /days. Blood glucose levels were $55.7 \pm 12.0$ on day 1 and increased on day 4 to $60.5 \%$, which was due to alloxan induction. After that the glucose level decreased on day 7,10 , and 14 , respectively by $2.1 \%, 6.3 \%$, $10.9 \%$. This could be caused by environmental conditions that result in stress leading to active movement, thus increasing tissue glucose utilization. This condition causes the blood glucose levels in mice to decrease.

In group D (ethanol extract of $50 \mathrm{mg} / \mathrm{kg}$ $\mathrm{BW} /$ day in $1 \mathrm{~mL}$ of $5 \%$ tween 80 ) on day 1 blood glucose levels were $57.2 \pm 10.7$ and increased by $56.7 \%$ and decreased again on day 7,10 , 14 , respectively by $5.8 \%, 11.6 \%, 25.4 \%$. At the end of treatment blood glucose levels returned back to normal. The decrease in blood glucose levels is presumably because of the metabolic compounds contained in the wungu leaf extract which are non-toxic alkaloids, glycosides, steroids, and saponins (Dalimartha 1999).

In group E ( diethyl ether extract of 50 $\mathrm{mg} / \mathrm{kg}$ bw / day in $1 \mathrm{~mL}$ of $5 \%$ tween 80 ) on day 1 blood glucose levels were $58.7 \pm 16.0$, decreasing on day 4 to $55.1 \%$ and decreased again on days $7,10,14$ by $8.8 \%, 22.7 \%, 7.1 \%$. This is because the diethyl ether-extracts-effect is thought to contain metabolic compounds. These 
metabolites in the mice body play a role in the mice to inhibit pancreatic $\beta$-cells from damage.

In group F (ethyl acetate extract $50 \mathrm{mg} /$ $\mathrm{kg} \mathrm{BW} /$ day in $1 \mathrm{~mL}$ of $5 \%$ tween 80 ) on day 1 blood glucose levels were $55.0 \pm 5.8$ and increased by $57.6 \%$ and decreased again on day 7 , 10,14 by $11.1 \%, 42.6 \%, 1.23 \%$. The decrease in blood glucose levels at the end of the treatment showed that the extract $\mathrm{F}$ can restore the function of the pancreas cell to their initial level, so that insulin can be produced again by the mice body, resulting in constant low blood glucose levels.

In group $\mathrm{G}$ (butanol extract of $50 \mathrm{mg} / \mathrm{kg}$ $\mathrm{BW} /$ day in $1 \mathrm{~mL}$ of $5 \%$ tween 80 ) on day 1 blood glucose levels were $53.2 \pm 11.5$ and an increase of $61.4 \%$ on day 4 and again decreased on day 7 , $10,13.5 \%, 54.7 \%$, and on day 14 , blood glucose levels go up by $14.5 \%$. It is predicted that the butanol extract was less stable in the mice pancreas and was not fully functioning to produce insulin, so the blood glucose levels rise again.

Fig 1. shows that wungu leaf extracts can lower blood glucose levels of mice, the most effective extract at the end of each treatment was the ethyl acetate extract with a decrease of blood glucose level of $37.6 \%$, after glibenclamide which caused a $56.5 \%$ reduction of glucose level. The second best extract was the butanol extract (32.6\% glucose reduction), and the least-well perform extracts were the ethanol extract (32.5\% glucose reduction) and the diethyl ether extract causing $30.1 \%$ glucose reduction. butanol extract was less stable in the mice pancreas and was not fully functioning to produce insulin, so the blood glucose levels rise again.

These data are supported by the statistical analysis showing that the end of treatment the blood glucuse level was significantly different $(p<0,05)$. This is presumably because of the metabolic compounds contained in the wungu leaf which are more soluble in the solvent ethyl acetate (semi polar) compared to the polar solvents such as butanol, ethanol and the non-polar solvents such as diethyl ether. In conclusion, wungu leaf extract at a dose of $50 \mathrm{mg} / \mathrm{kg}$ BW can decrease blood glucose of alloxan induced mice. The best extract is the ethyl acetate extract with an efficiency in decreasing blood glucose of $37.6 \%$.

\section{ACKNOWLEDGEMENT}

Thank you to the DIKTI which has provided funds through BOPTN (Operational Support for State College).

\section{REFERENCES}

Dalimartha, S. 1999. Atlas Tumbuhan Obat Indonesia. Jilid 1. Jakarta: Trubus Agriwidya.

Fahri C, Sutarno, Listyawati S. 2005. Kadar Glukosa dan Kolesterol Total Darah Tikus Putih (Rattus norvegicus L.) Hiperglikemik setelah Pemberian Ekstrak Metanol Akar Meniran (Phyllanthus niruri L.). Biofarmasi 3 : 1-6, Pebruari, ISSN: 1693-2242.

Nurcholis W, Andrianto D, Falah S, Katayama T. 2011. $\alpha$-Glucosidase Inhibitor and cytotoxic activities and phytochemical sceening of Graptophyllum pictum (L.) griff. The 3rd International Symposium of Indonesian Wood Reseach Society, YogyakartaIndonesia, November 3rd to 4th, 2011.

Olagbende-Dada SO, Coker HAB, Ukpo GE, Adesina SA. 2009. Oxytocic and antiimplantation activities of the leaf extracts of Graptophyllum pictum (Linn.) Griff. (Acanthaceae). Afr. J. Biotechnol 8: 59795984.

Olagbende-Dada SO, Ogbonia SO, Coker HAB, Ukpo GE. 2011. Blood glucose lowering 
effect of aqueous extract of Graptophyllum pictum (Linn.) Griff. On alloxan-induced diabetic rats and its acute toxicity in mice. Afr. J. Biotechnol 10: 1039-1043.

Rauter AP, Martin A, Lopes R, Ferreira J, Serralheiro LM, Araujo ME, Borges C, Justino J, Silva FV. 2009. Bioactivity studies and chemical profile of the antidiabetic plant genista terena. Journal of Enthopharmacology 122: 384-393.

Studiawan H and Santosa MH. 2005. Uji Aktivitas Penurunan Kadar Glukosa Darah Ekstrak Daun Eugenia polyantha pada Mencit yang Diinduksi Aloksan. Media Kedokteran Hewan 21: 62-65.

Suhargo L. 2005. Efek estrogenik ekstrak daun handeuleum (Graptophyllum pictum (L.) Griff) pada histologi uterus mencit betina ovariektomi. Berk. Penel. Hayati 10: 107110.

Sunarsih ES, Djatmika, Utomo RS. 2007. Pengaruh pemberian infusa umbi gadung (Dioscorea hispida Densst) terhadap penurunan kadar glukosa darah tikus putih jantan diabetes yang diinduksi aloksan. Majalah Farmasi Indonesia 18: 29-33. Widyowati R. 2011. Alkaline phosphatase activity of Graptophyllum pictum and Sphilanthes acmella fractions against MC3T3-E1 cells as marker of osteoblast differentiation cells. Int J Pharm Pharm Sci 3: 34-37.

Zuhra CF, Lenny S. 2005. Isolasi dan uji bioaktivitas kandungan utama pudding merah (Graptophyllum pictum (L.) Griff) dengan metode uji brine shrimp. Jurnal Komunikasi Penelitian 17: 56-59. 